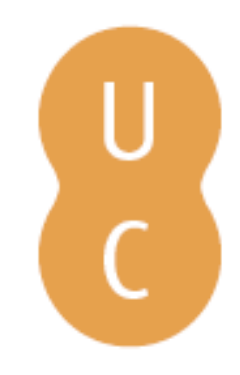

\title{
nombalina
}

\section{Physiological and functional characteristics of adolescent athletes in several sports: implications for talent identification}

\author{
Autor(es): Bunc, Vaclav \\ Publicado por: Coimbra University Press \\ URL \\ persistente: URI:http://hdl.handle.net/10316.2/32634 \\ DOI: $\quad$ DOI:http://dx.doi.org/10.14195/978-989-26-0412-1_18 \\ Accessed : $\quad$ 26-Apr-2023 14:02:24
}

A navegação consulta e descarregamento dos títulos inseridos nas Bibliotecas Digitais UC Digitalis, UC Pombalina e UC Impactum, pressupõem a aceitação plena e sem reservas dos Termos e Condições de Uso destas Bibliotecas Digitais, disponíveis em https://digitalis.uc.pt/pt-pt/termos.

Conforme exposto nos referidos Termos e Condições de Uso, o descarregamento de títulos de acesso restrito requer uma licença válida de autorização devendo o utilizador aceder ao(s) documento(s) a partir de um endereço de IP da instituição detentora da supramencionada licença.

Ao utilizador é apenas permitido o descarregamento para uso pessoal, pelo que o emprego do(s) título(s) descarregado(s) para outro fim, designadamente comercial, carece de autorização do respetivo autor ou editor da obra.

Na medida em que todas as obras da UC Digitalis se encontram protegidas pelo Código do Direito de Autor e Direitos Conexos e demais legislação aplicável, toda a cópia, parcial ou total, deste documento, nos casos em que é legalmente admitida, deverá conter ou fazer-se acompanhar por este aviso.

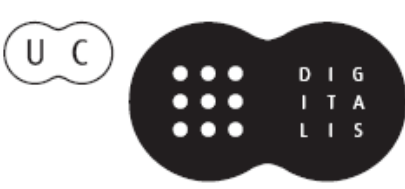


MANUEL COELHO E SILVA

ROBERT M. MALINA

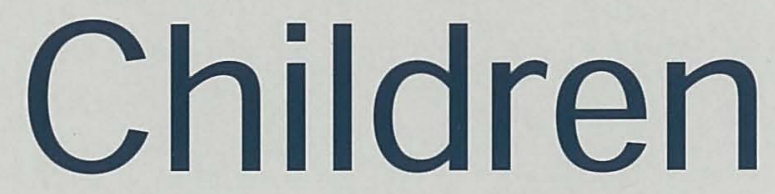

\section{and Youth}

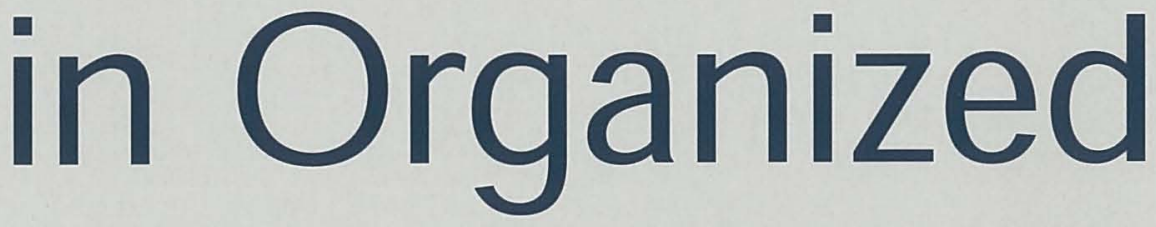

Sports 
(Página deixada propositadamente em branco) 
Manuel Coelho e Silva

Robert M. Malina

(Editors)

CHILDREN AND YOUTH IN ORGANIZED SPORTS

COIMBRA UNIVERSITY PRESS

2004 


$$
\begin{gathered}
\text { Editors } \\
\text { Manuel Coelho e Silva } \\
\text { and } \\
\text { Robert M. Malina } \\
\text { Publisher } \\
\text { Imprensa da Universidade de Coimbra } \\
\text { Coimbra University Press } \\
\text { Title } \\
\text { Children and Youth in Organized Sports }
\end{gathered}
$$

Date

March 2004

ISBN

972-8704-21-6

(Depósito legal n.: 208058/04)

Financial support

FCT Fundação para a Ciência e a 'Tecnologia MINISTÉRIO DA CIÊNCIA E DO ENSINO SUPERIOR Portugal

$$
\text { Apoio do Programa Operacional }
$$

Ciência, Tecnologia, Inovação do Quadro Comunitário de Apoio III

e

Câmara Municipal da Lousã

Faculdade de Ciências do Desporto e Educação Física

Universidade de Coimbra 


\title{
PHYSIOLOGICAL AND FUNCTIONAL CHARACTERISTICS OF ADOLESCENT ATHLETES IN SEVERAL SPORTS: IMPLICATIONS FOR TALENT IDENTIFICATION
}

\author{
Vaclav Bunc \\ Faculty of Physical Education and Sports. Charles University. Prague. \\ CZECH REPUBLIC
}

\section{INTRODUCTION}

The body size and composition of adolescent athletes receive considerable attention in discussions of adolescent athletes in a variety of sports. Of equal and perhaps more importance are functional and physiological characteristics associated with, on one hand, muscular strength, power and endurance, and on the other hand, aerobic and anaerobic capacities. These characteristics are often included in inventories aimed at identifying potentially talented young athletes in many sports. The identification process is influenced, of course, by the course of normal growth and maturation which are highly individual processes. As a result, there is considerably inter-individual variation, especially during the adolescent growth spurt. Likewise, there is considerable variation in the responsiveness to training, i.e., trainability, during adolescence. In later adolescence, adult size is almost attained, whereas functional variables continue to develop. Hence, it is appropriate to consider the physiological characteristics of late adolescent athletes. This paper thus presents a profile of the body size, composition and physiological characteristics of elite late adolescent athletes in a variety of sports.

\section{METHODS}

\section{I. Subjects}

The subjects were top Czech athletes of both sexes, 249 males and I 46 females, in nine sports: triathlon, long and middle distance running, crosscountry skiing, cycling, soccer, basketball, canoeing, swimming. All subjects trained at least 6 days a week and had been engaged in high-intensity training for at least 5 years. The mean time spent in intensive training was about two hours per session. The best of the athletes competed regularly at international events and were successful in European and/or World junior Championships. As a group, the sample can be labelled as including the best, young Czech athletes. 


\subsection{Methods}

Height and weight were measured. Body composition was estimated with whole-body impedance using a commercially available bio-impedance system (BIA 2000-M). A tetrapolar electrode configuration with the subject in a supine position on the right hand and foot in positions which are recommended by producer. Prior to positioning the electrodes, each site was prepared by swabbing with alcohol and then allowed to dry. A current of 400 $\mu \mathrm{A}$ at frequencies $1,5,50$, and $100 \mathrm{kHz}$ was introduced to the subject. Capacitance and resistance (angle between these variables) from whole impedance were used to derive estimates of extra-cellular mass (ECM) and body cell mass (BCM). The ratio of ECM to BCM was used as an estimate of muscle mass.

An incremental exercise test to subjective exhaustion on a treadmill at $5 \%$ inclination was used to estimate oxygen uptake and $\mathrm{VO}_{2}$ max. The initial speed of running ranged from $9 \mathrm{~km} \cdot \mathrm{h}^{-1}$ to $13 \mathrm{~km} \cdot \mathrm{h}^{-1}$ depending on the speed predisposition of the subjects. The running speed was increased each minute by $1 \mathrm{~km} . \mathrm{h}^{-1}$ until subjective exhaustion. Heart rate was monitored by means of short-range radio telemetry (Sporttester, Polar). The computer printed out these values every $30 \mathrm{~s}$. The maximal value was defined as the mean of the two highest consecutive values.

Respiratory variables and gas exchange were measured using an open system. The athletes breathed through a two-way valve with a small dead space (laeger or TEEM 100). Pulmonary ventilation was measured using a pneumotachograph (Jaeger or TEMM 100) calibrated before and after each test by a mechanical pump. The oxygen concentration was measured using a paramagnetic analyser and the $\mathrm{CO}_{2}$ concentration using an infrared analyser (both Jaeger). Both analysers were calibrated throughout the physiological range of measurement using gases of known concentration. Both instruments were compared and the differences between the data determined by both were less than $1.5 \%$.

The coefficients of energy cost of running were calculated from the maximal intensity of exercise where a reliable relationship between the intensity of exercise and the energy expenditure was still observed. This corresponds to the anaerobic threshold, in the present study the ventilatory threshold (VT). Although many non-invasive methods may be used, a nonlinear increase in pulmonary ventilation with respect of $\mathrm{VO}_{2}$ or $\mathrm{VCO}_{2}$ is at present the simplest, and probably the most accurate method for determining the $V T$. The criterion for $V T$ determination was a non-linear increase in pulmonary ventilation versus $\mathrm{VO}_{2}$ or $\mathrm{VCO}_{2}$ (Bunc et al., 1987). The ventilatory threshold was assessed by means of a two-compartment linear model using 
these relationships. This was done with a computer algorithm to establish a two-line regression intersection point .

Blood lactate concentration was measured in the third minute after finishing the exercise from samples of arterialized blood collected from the finger tip. The enzymatic method (Boehringer kits) was used to analyse the blood sample.

\section{RESULTS}

Descriptive statistics for age, height, weight and estimated body composition are summarized by sport for male and females athletess, respectively, in Tables I and 2. With the exception of basketball players (196.I $\mathrm{cm}$ ) followed by swimmers $(182.3 \mathrm{~cm})$, mean heights of male athletes in the other sports vary within a relatively narrow range, $176.8 \mathrm{~cm}$ to $180.6 \mathrm{~cm}$. Mean weights of male athletes are more variable, ranging from $63.09 \mathrm{~kg}$ for long distance runners to $85.4 \mathrm{~kg}$ for basketball players. In contrast to body weight, estimated relative fatness and the ratio of ECM/BCM, on average, fluctuate within a relatively narrow range.

Table I. Means and standard deviations for age and physical characteristics of late adolescent male athletes.

\begin{tabular}{l|c|c|c|c|c|c|c|c|c|c|c}
\hline Sport & $\mathrm{n}$ & \multicolumn{2}{|c|}{$\begin{array}{c}\text { age } \\
\text { (years) }\end{array}$} & \multicolumn{2}{c|}{$\begin{array}{c}\text { mass } \\
(\mathrm{kg})\end{array}$} & \multicolumn{2}{c|}{$\begin{array}{c}\text { height } \\
(\mathrm{cm})\end{array}$} & \multicolumn{2}{c|}{ \%fat } & \multicolumn{2}{c}{ ECM/BCM } \\
\hline Triathlon & 58 & 17.3 & 1.8 & 69.5 & 6.9 & 179.6 & 4.1 & 10.4 & 2.2 & 0.72 & 0.06 \\
L.D. running & 29 & 17.0 & 0.8 & 63.9 & 4.9 & 178.1 & 4.5 & 8.0 & 1.9 & 0.71 & 0.07 \\
M.D. running & 35 & 17.4 & 1.1 & 66.2 & 4.1 & 179.5 & 4.0 & 9.0 & 2.0 & 0.70 & 0.09 \\
C.C. skiing & 28 & 17.3 & 0.8 & 67.5 & 4.1 & 176.8 & 3.4 & 8.1 & 3.0 & 0.71 & 0.08 \\
Biathloni & 56 & 17.4 & 0.7 & 68.2 & 3.8 & 179.3 & 3.2 & 9.4 & .2 .7 & 0.72 & 0.07 \\
Cycling & 15 & 17.5 & 0.6 & 65.9 & 3.1 & 177.0 & 3.0 & 8.6 & 1.4 & 0.72 & 0.08 \\
Soccer & 32 & 16.9 & 1.2 & 70.9 & 3.0 & 180.6 & 2.1 & 9.6 & 1.2 & 0.74 & 0.07 \\
Basketball & 17 & 17.4 & 0.9 & 85.4 & 2.9 & 196.1 & 4.2 & 11.9 & 1.6 & 0.78 & 0.10 \\
Squash & 16 & 16.8 & 1.8 & 66.5 & 3.0 & 178.5 & .5 & 9.7 & 2.1 & 0.76 & 0.08 \\
Tennis & 12 & 16.9 & 1.5 & 68.5 & 2.7 & 179.1 & 3.7 & 10.2 & 2.2 & 0.77 & 0.09 \\
Canoeing & 21 & 17.4 & 0.8 & 74.5 & 5.1 & 179.5 & 4.6 & 11.4 & 1.9 & 0.70 & 0.06 \\
Swimming & 14 & 17.3 & 0.9 & 73.6 & 3.5 & 182.3 & 3.2 & 12.0 & 2.4 & 0.73 & 0.11 \\
\hline
\end{tabular}

The distribution of mean heights of female athletes is similar to that of

male athletes. Basketball players are, on average, tallest $(183.1 \mathrm{~cm})$, whereas the heights of athletes in other sports vary within a relatively narrow range, $167.3 \mathrm{~cm}$ for long distance runners to $172.6 \mathrm{~cm}$ for swimmers. The mean height of the small sample of female soccer players, $165.3 \mathrm{~cm}$, appears to be an exception. Mean weights of female athletes are a bit more variable, $56.3 \mathrm{~kg}$ in soccer players to $65.7 \mathrm{~kg}$ in canoeists. The range of estimated relative fatness and ECM/BCM in female athletes is greater than the corresponding 
range in males. The estimated fatness of female athletes was greater than in male athletes in the same sport.

Table 2. Means and standard deviations for age and physical characteristics of late adolescent female athletes.

\begin{tabular}{l|c|c|c|c|c|c|c|c|c|c|c}
\hline Sport & $\mathrm{n}$ & \multicolumn{2}{|c|}{$\begin{array}{c}\text { age } \\
(\text { years })\end{array}$} & \multicolumn{2}{c|}{$\begin{array}{c}\text { mass } \\
(\mathrm{kg})\end{array}$} & \multicolumn{2}{c|}{$\begin{array}{c}\text { height } \\
(\mathrm{cm})\end{array}$} & \multicolumn{2}{c|}{ \%fat } & \multicolumn{2}{c}{ ECM/BCM } \\
\hline Triathlon & 39 & 17.1 & 1.1 & 61.3 & 3.6 & 169.3 & 2.0 & 12.5 & 1.9 & 0.74 & 0.08 \\
L.D. running & 12 & 17.1 & 0.9 & 56.8 & 1.9 & 167.3 & 2.1 & 9.4 & 1.3 & 0.73 & 0.10 \\
M.D. running & 18 & 17.2 & 1.0 & 57.3 & 2.2 & 169.5 & 2.4 & 10.3 & 2.0 & 0.72 & 0.09 \\
C.C. skiing & 16 & 17.4 & 1.1 & 59.2 & 1.9 & 171.2 & 2.1 & 9.5 & 1.4 & 0.72 & 0.08 \\
Biathlon & 41 & 17.2 & 0.8 & 61.3 & 1.7 & 171.8 & 1.8 & 10.6 & 1.5 & 0.73 & 0.09 \\
Cycling & 11 & 17.1 & 0.8 & 57.4 & 2.4 & 168.3 & 1.9 & 11.1 & 1.7 & 0.74 & 0.09 \\
Soccer & 10 & 16.9 & 0.7 & 56.3 & 2.1 & 165.3 & 1.7 & 13.0 & 1.9 & 0.80 & 0.08 \\
Basketball & 12 & 17.0 & 0.8 & 72.3 & 2.6 & 183.1 & 1.9 & 14.2 & 2.1 & 0.83 & 0.07 \\
Squash & 14 & 16.3 & 0.8 & 57.4 & 5.0 & 167.2 & 4.0 & 14.5 & 2.0 & 0.86 & 0.10 \\
Tennis & 11 & 16.5 & 0.9 & 58.5 & 4.0 & 168.1 & 3.6 & 14.7 & 2.2 & 0.87 & 0.08 \\
Canoeing & 15 & 16.5 & 0.8 & 65.7 & 5.2 & 172.3 & 4.1 & 12.8 & 1.6 & 0.76 & 0.08 \\
Swimming & 13 & 17.2 & 1.1 & 64.8 & 2.5 & 172.6 & 2.0 & 13.9 & 1.9 & 0.75 & 0.10 \\
\hline
\end{tabular}

The profiles of maximal functional variables for male and female athletes are summarized in Tables 3 and 4, respectively, both groups of young athletes. There are small and non-significant differences in maximal oxygen uptake among endurance athletes of both sexes (triathlon, cross country skiing, long and middle distance runners, cyclists), whereas maximal oxygen uptake of endurance athletes is, on average, greater than in swimmers and team sport athletes.

Table 3. Means and standards deviation of selected maximal functional variables based on treadmill ergometry (\%5 slope) in late adolescent male athletes.

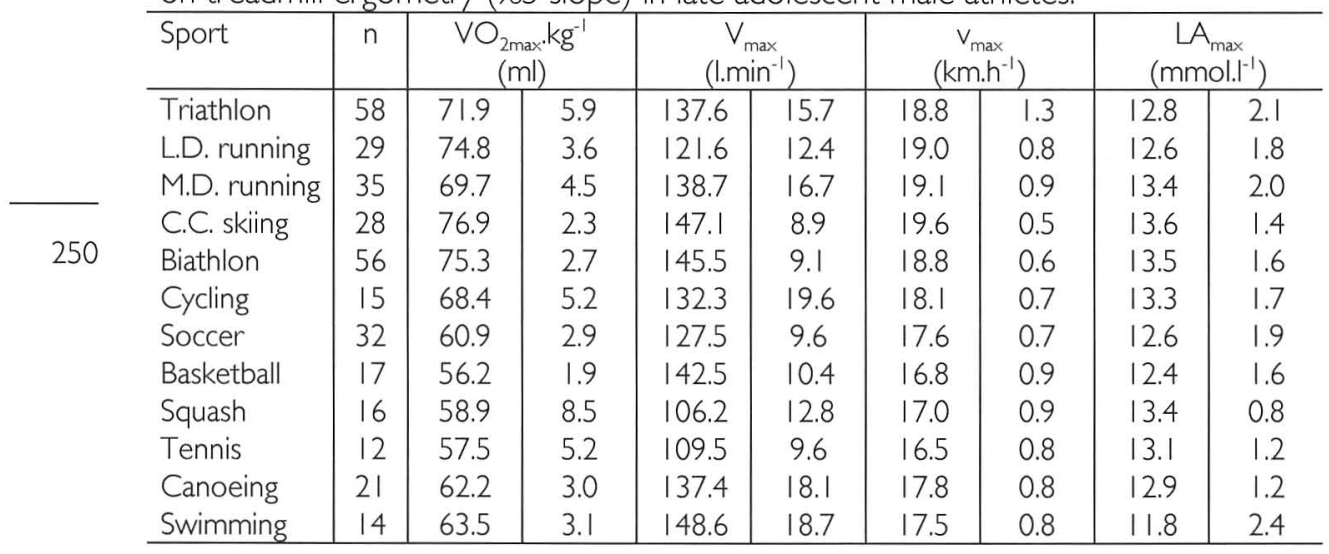


Table 4. Means and standard deviations of selected maximal functional variables based on treadmill ergometry (\%5 slope) in late adolescent female athletes.

\begin{tabular}{l|c|c|c|c|c|c|c|c|c}
\hline Sport & $\mathrm{n}$ & \multicolumn{2}{|c|}{$\begin{array}{c}\text { VO2max.kg-I } \\
(\mathrm{ml})\end{array}$} & \multicolumn{2}{c|}{$\begin{array}{c}\text { Vmax } \\
(\mathrm{l} . \mathrm{min}-1)\end{array}$} & \multicolumn{2}{c|}{$\begin{array}{c}\mathrm{vmax} \\
\left(\mathrm{km} . \mathrm{h}^{-1}\right)\end{array}$} & \multicolumn{2}{c}{$\begin{array}{c}L_{\text {max }} \\
\left(\mathrm{mmol}^{-1}\right)\end{array}$} \\
\hline Triathlon & 39 & 61.9 & 2.4 & 126.6 & 13.0 & 15.7 & 0.6 & 12.7 & 1.2 \\
L.D. running & 12 & 65.7 & 2.6 & 119.3 & 12.4 & 16.4 & 0.6 & 12.5 & 1.6 \\
M.D. running & 18 & 62.3 & 2.1 & 118.6 & 12.7 & 16.4 & 0.8 & 13.7 & 2.4 \\
C.C. skiing & 16 & 66.5 & 2.3 & 119.1 & 8.6 & 16.3 & 0.9 & 13.3 & 2.0 \\
Biathlon & 41 & 64.7 & 2.0 & 117.5 & 9.1 & 16.0 & 0.9 & 13.0 & 1.8 \\
Cycling & 11 & 59.8 & 2.0 & 116.2 & 12.9 & 15.4 & 0.8 & 12.9 & 1.8 \\
Soccer & 10 & 50.6 & 1.6 & 94.1 & 7.8 & 14.7 & 0.6 & 12.1 & 1.2 \\
Basketball & 12 & 48.9 & 1.8 & 109.5 & 6.4 & 14.3 & 0.7 & 12.0 & 1.8 \\
Squash & 14 & 53.4 & 5.7 & 86.8 & 6.0 & 14.5 & 0.9 & 13.0 & 0.7 \\
Tennis & 11 & 52.9 & 3.2 & 90.8 & 8.4 & 14.3 & 0.8 & 13.1 & 1.0 \\
Canoeing & 15 & 51.8 & 2.3 & 120.3 & 11.8 & 15.6 & 0.9 & 13.0 & 1.6 \\
Swimming & 13 & 57.9 & 2.2 & 133.4 & 14.8 & 15.2 & 0.5 & 11.7 & 2.4 \\
\hline
\end{tabular}

Table 5. Means and standard deviations for selected functional variables at VT and the coefficient of energy cost of running (C. with treadmill with slope of $5 \%$ ) in late adolescent male athletes.

\begin{tabular}{|c|c|c|c|c|c|c|c|c|c|c|c|}
\hline \multirow{2}{*}{$\begin{array}{l}\text { Sport } \\
\text { Triathlon }\end{array}$} & \multirow{2}{*}{$\begin{array}{l}n \\
58\end{array}$} & \multicolumn{2}{|c|}{$\begin{array}{c}\text { VO2.kg-I } \\
(\mathrm{ml})\end{array}$} & \multicolumn{2}{|c|}{ \%VO2max.kg-I } & \multicolumn{2}{|c|}{$\begin{array}{c}V \\
(\mathrm{~km} \cdot \mathrm{h}-\mathrm{l})\end{array}$} & \multicolumn{2}{|c|}{ \%vmax } & \multicolumn{2}{|c|}{$\begin{array}{c}C \\
(. . \mathrm{kg}-\mathrm{l} . \mathrm{m}-\mathrm{l})\end{array}$} \\
\hline & & 59.5 & 4.9 & 82.7 & 2.1 & 15.4 & 1.5 & 81.9 & 2.6 & 3.74 & 0.13 \\
\hline L.D. running & 29 & 62.8 & 4.5 & 83.9 & 2.9 & 16.1 & 1.8 & 84.7 & 2.3 & 3.70 & 0.11 \\
\hline M.D. running & 35 & 57.8 & 4.2 & 82.9 & 2.7 & 16.2 & 2.0 & 84.9 & 2.0 & 3.69 & 0.10 \\
\hline C.C. skiing & 28 & 64.4 & 2.8 & 83.7 & 1.9 & 15.8 & 0.7 & 80.6 & I.1 & 3.74 & 0.09 \\
\hline Biathlon & 56 & 62.4 & 2.1 & 82.8 & 1.6 & 15.1 & 0.6 & 80.3 & 1.0 & 3.75 & 0.09 \\
\hline Cycling & 15 & 57.0 & 5.1 & 83.3 & 2.3 & 14.9 & 1.2 & 82.5 & 2.9 & 3.80 & 0.12 \\
\hline Soccer & 32 & 48.6 & 3.1 & 79.8 & 2.6 & | 3.8 & 0.9 & 80.4 & 1.6 & 3.76 & 0.10 \\
\hline Basketball & 17 & 44.2 & 1.0 & 78.6 & 2.0 & 12.8 & 0.8 & 76.3 & 2.0 & 3.90 & 0.11 \\
\hline Squash & 16 & 46.6 & 1.9 & 79.2 & 1.6 & | 3.4 & 0.5 & 78.8 & 2.3 & 3.84 & 0.12 \\
\hline Tennis & 12 & 45.2 & 2.1 & 78.6 & 2.4 & | 3.2 & 0.6 & 80.0 & 2.1 & 3.87 & 0.10 \\
\hline Canoeing & 21 & 49.4 & 3.1 & 78.9 & 2.0 & 14.1 & 0.5 & 79.3 & 2.4 & 3.86 & 0.14 \\
\hline Swimming & 14 & 50.4 & 3.7 & 80.3 & 2.2 & 14.2 & 1.8 & 81.1 & 1.9 & 3.84 & 0.09 \\
\hline
\end{tabular}

Descriptive statistics for selected functional variables at the ventilatory threshold are given in Tables 5 and 6 for male and female athletes, respectively. The coefficient of energy cost of running $(C)$ is also included in the tables. The functional variables at VT are practically identical among endurance oriented athletes of both sexes.

Correlations between laboratory variables and performance (race times) variables were calculated for the sample of endurance athletes. The performance times were obtained three after the laboratory tests in the athletes. Performance time was not related to pulmonary ventilation and blood lactate in a combined sample of male and female athletes. In contrast, 
the relationship between competition performance and several other functional variables were moderate to high: maximal oxygen uptake in ml.kgI.min-I (males, -0.63 to -0.81 ; females, -0.7 I to -0.88 ), maximal speed of treadmill running (males, -0.60 to -0.81 ; females, -0.66 to -0.87 ), speed of running at the anaerobic threshold level (males, -0.56 to -0.82 ; females, -0.7 I to -0.78$)$.

Table 6. Means and standard deviations for selected functional variables at VT and the coefficient of energy cost of running (C. with treadmill with slope of 5\%) in late adolescent female athletes.

\begin{tabular}{|c|c|c|c|c|c|c|c|c|c|c|c|}
\hline \multirow{2}{*}{$\begin{array}{l}\text { Sport } \\
\text { Triathlon }\end{array}$} & \multirow{2}{*}{$\begin{array}{l}\mathrm{n} \\
39\end{array}$} & \multicolumn{2}{|c|}{$\begin{array}{l}\text { VO2.kg-I } \\
(\mathrm{ml})\end{array}$} & \multicolumn{2}{|c|}{$\begin{array}{c}\text { \%VO2max.kg- } \\
\text { । }\end{array}$} & \multicolumn{2}{|c|}{$\begin{array}{c}v \\
(k m \cdot h-l)\end{array}$} & \multicolumn{2}{|c|}{ \%vmax } & \multicolumn{2}{|c|}{$\begin{array}{c}\mathrm{C} \\
\left(\mathrm{J} \cdot \mathrm{kg}^{-1} \cdot \mathrm{m}^{-1}\right)\end{array}$} \\
\hline & & 51.4 & 2.9 & 83.1 & 1.9 & 13.2 & 0.8 & 84.0 & 1.9 & 3.71 & 0.13 \\
\hline L.D. running & 12 & 54.3 & 3.4 & 83.7 & 2.0 & 13.8 & 1.0 & 84.3 & 2.1 & 3.71 & 0.09 \\
\hline M.D. running & 18 & 51.6 & 2.7 & 82.9 & 2.3 & 13.7 & 1.2 & 83.7 & 2.2 & 3.70 & 0.10 \\
\hline C.C. skiing & 16 & 55.2 & 2.8 & 83.0 & 2.0 & 13.6 & 1.3 & 84.0 & 2.1 & 3.74 & 0.09 \\
\hline Biathlon & 41 & 53.1 & 2.2 & 82.1 & 1.7 & 12.8 & 1.2 & 80.0 & 1.8 & 3.76 & 0.08 \\
\hline Cycling & 11 & 49.7 & 2.9 & 83.1 & 2.4 & 12.6 & 0.9 & 82.0 & 2.5 & 3.82 & 0.08 \\
\hline Soccer & 10 & 39.6 & 1.8 & 78.1 & 1.6 & 11.7 & 0.6 & 79.8 & 2.0 & 3.84 & 0.07 \\
\hline Basketball & 12 & 38.0 & 1.7 & 77.6 & 1.8 & 11.3 & 0.7 & 79.2 & 1.8 & 3.86 & 0.08 \\
\hline Squash & 14 & 42.6 & 1.6 & 79.7 & 1.6 & 11.9 & 0.9 & 82.1 & 1.9 & 3.82 & 1.00 \\
\hline Tennis & 11 & 41.8 & 2.0 & 79.0 & 1.9 & 11.7 & 0.8 & 81.8 & 2.2 & 3.85 & 0.09 \\
\hline Canoeing & 15 & 41.0 & 2.4 & 79.1 & 1.8 & 12.4 & I.1 & 79.8 & 2.0 & 3.84 & 0.09 \\
\hline Swimming & 13 & 46.8 & 3.0 & 80.9 & 1.7 & 12.4 & 1.1 & 81.5 & 2.0 & 3.86 & 0.10 \\
\hline
\end{tabular}

\section{DISCUSSION}

Nowadays is currently running the debate about the basic physiological nature of majority modern sports events, particularly about the relative importance of the aerobic and anaerobic energy systems and about the degree of involvement of the lactic acid system.

The significance of the aerobic energy system may be clarified by considering the values for maximal oxygen uptakes of soccer players obtained in numerous studies over the years.

The young trained athletes typically manifest maximal oxygen values of 60-65 ml.kg- I.min-I approximately 20-30\% higher than the values of VO2max expected from general population (Astrand and Rodahl, 1986, Bunc, 1989). There are no significant differences in the maximal oxygen uptake between systematically trained children whose training is oriented toward running (fitness orientation) or playing (skill development orientation). This observation is valid even if the children train three times per week, 70 minutes per practice. 
In young subjects, the combined aerobic plasticity, represented by the change in oxygen uptake in the values measured at the complete bed rest to the values measured during endurance training appears to be about 20-25\% lower than oxygen uptake during endurance training (Astrand and Rodahl 1986).

In adults, the maximal oxygen uptake of $60 \mathrm{ml} . \mathrm{kg}$ - I.min-I seems to be sufficient even at high performance levels of majority players, although there are studies, which suggests that $65 \mathrm{ml} . \mathrm{kg}-\mathrm{I} . \mathrm{min}-\mathrm{I}$ is necessary for top level adult competition (Tumilty, 1993; Reilly et al., 1990). Values of oxygen uptake around $60 \mathrm{ml} . \mathrm{kg}-\mathrm{I}$.min- I are about $10 \mathrm{ml} . \mathrm{kg}-\mathrm{I}$. min- I above the average for the general population of the same age, but are at least $15 \mathrm{ml} . \mathrm{kg}$ - I.min-I below the oxygen uptake of long distance runners and cross-country skiers (Astrand and Rodahl, 1986; Bunc and Heller, 1989). Soccer players, therefore, seem to have good but not exceptional aerobic capacity.

High values of maximal oxygen uptake per unit body mass are typical for athletes with high endurance abilities (Astrand and Rodahl, 1986; Maud and Foster, 1995; Rowland, 1996). Both specific muscle mass and oxidative capacity of working muscles may be increased by specific training and thus the VO2max.kg-I may reflect a specific predisposition for endurance exercise. Maximal oxygen uptake in trained athletes is generally higher in work situations that allow optimal use of specifically trained muscle fibres VO2max.kg-I (Wilmore and Costill, 1994). This may underlie some of the differences in "running" VO2max.kg-I when results of specialists in middle-distance running, cycling and swimming are compared.

The values of maximal functional variables (largely maximal oxygen uptake) are similar to those of top young Czech middle-distance runners and/or cyclists and slightly higher than elite top swimmers of the same age, which were evaluated by the same protocol. These values are lower than those found in Czech top long-distance runners of the same age. The majority of the young athletes started regular sports training in cycling and/or running. In contrast the majority of adult athletes are according to their basic singlesport orientation swimmers.

Maximal oxygen uptake has routinely been used to assess endurance running performance. In fact, successful performance in competitive distance running has been primarily attributed to $\mathrm{VO}_{2 \text { max }} \mathrm{kg}^{-1}$. A number of investigators have reported significant correlations between maximal oxygen uptake per unit body mass and success in distance running (Astrand and Rodahl, 1986; Dengel, 1989; OToole and Douglas, 1995).

The range of $\mathrm{VO}_{2 \max } \mathrm{kg}^{-1}$ was relatively large in all groups of endurance oriented athletes, and these values are slightly lower than values in top adult 
athletes of the same sports event. The higher values in maximal oxygen uptake in subjects with higher performance levels suggest that a high maximal oxygen uptake is necessary to become a world-class athlete. Thus, there may only be limited possibilities to compensate for a low $V O_{2 \max } \cdot \mathrm{kg}^{-1}$. A high level of maximal oxygen uptake per se does not guarantee good performance, since technique and psychological factors may exert either positive or negative influences. In practice, this implies that both laboratory and performance must be considered simultaneously.

The literature regarding the physiological characteristics of elite young endurance athletes shows that nearly all male competitors have $\mathrm{VO}_{2 \text { max }} \mathrm{kg}^{-1}$ values higher than 73 and females higher than $65 \mathrm{ml} . \mathrm{kg}^{-1} \cdot \mathrm{min}^{-1}$ (Astrand and Rodahl, 1986; Wilmore and Costill, 1994). Thus, a high maximal oxygen uptake unit body mass is often considered a prerequisite for success in endurance sports. The importance of the run segment to overall triathlon performance was recently made evident by a study which noted it to be the best predictor of overall time in a triathlon (O Toole and Douglas, 1995).

The higher values of maximal oxygen uptake in adults than in the young athletes can be explained by the higher training state of adults, i.e. a higher degree of adaptation to exercise. The higher energy cost of running - lower running economy in young soccer players confirms this conclusion.

The other two potential factors, which could explain physiological difference between very young and adult athletes are:

A small difference in relative $V_{2 \max } \cdot \mathrm{kg}^{-1}$ between young and adult players (compared to a larger difference in the absolute values of oxygen uptake in young and adult trained players) may be related, in part, to a greater variation in body composition in younger subjects. As stated by Cureton et al. (1978), the increased body fat lowers the maximal oxygen uptake (expressed relative to body mass), because it increases body mass without contributing to oxygen use.

- The nature of training stimulus influences the capacity for improvement of maximal oxygen uptake.

The significantly lower values of $\mathrm{LA}_{\max }$ and confirm the lower anaerobic capacity of young athletess comparing to adults. This situation is well documented in literature (e.g. Astrand and Rodahl, 1986).

Metabolic adaptation, which can be indirectly characterized as the ability to utilize effective the functional capacity of the organism during a prolonged period, can be estimated as the percentage of maximal functional variables (mainly maximal oxygen uptake) at VT (Bunc et al., 1987). In untrained 
subjects, $\% \mathrm{VO}_{2 \text { max }} \mathrm{kg}^{-1}$ is in the range of $50 \%-70 \%$ of maximal oxygen uptake; in trained subjects, values are in the range of $80 \%-90 \%$ of VO2max (Bunc et al., 1987; Wilmore and Costill, 1994)

The higher the level of adaptation to physical activity, the higher the values of $\% \mathrm{VO}_{2 \max }$ at the $\mathrm{VT}$ level. The untrained children of the same age as our young players, which were evaluated in our laboratory by the same protocol had values of $\% \mathrm{VO}_{2 \max }$ in the range of $60-70 \%$. The young long distance runners had the same values ranging from $80 \%$ to $86 \%$.

Balsom (1988) found no significant correlation between performance decrement and anaerobic threshold expressed as percentage of maximal oxygen uptake. His moderately trained college players had a threshold value of $70.5 \%$ of maximal oxygen uptake, which is somewhat lower than the values reported by several other investigators. The adult players in our older study (Bunc et al., 1987) had a \% VO ${ }_{2 \max }$ value of $80.5 \%$. Rhodes et al. (1986) found the same value of $\% \mathrm{VO}_{2 \max }$ in the Canadian Olympic Team and considered it to be "remarkably high for anaerobically trained athletes".

The dilemma for the coach and player is to determine how to improve fitness through an organized fitness programme without sacrificing player's game performance and without neglecting skill development, which gave game its unique character. This is a special concern for very young players, who must firstly try to improve their basic motor abilities. It is likely that an increase in fitness level will be more useful if there is an improvement in the player's skill and the game sense.

As in other sports, where skills play an important role, the functional data are not the sole predictor of game success, but they play a decisive role in the selection of young players for competitive soccer teams and for a long term training process.

The total energy cost of training loads imposed on the group of young athletes during the year was more or less independent of the quantitative and qualitative structure of training. Almost constant energy demands of the training programme resulted in practically constant values of maximal functional variables associated with maximal oxygen uptake per $\mathrm{kg}$ body mass during one year of training. Any change in the functional variables can only result from the basic alterations in the quality and, in particular, the quantity of training programs for top level soccer players. These changes are most unlikely to occur during a single year. This suggests that the maximal oxygen uptake related to $\mathrm{kg}$ body mass can be changed in trained athletes only with a great difficulty, consequently it has a little practical use for evaluating the effect of the training stimulus on the course of adaptation to this level of exercise (Brooks, 1985; Bunc et al., 1987; Costill, 1976). 
The changes in absolute values of maximal oxygen uptake in children are mainly connected with changes in the body mass (Astrand and Rodahl, 1986). On the other hand, the changes in energy cost of moving, generally in adaptation to exercise, are significantly influenced by the duration of training.

The coefficient $C$ can be used for the evaluation of the adaptation to the specific movements of a sport (Bunc and Heller, 1989). The higher the level of adaptation to a given type of exercise, the lower the amount of energy necessary to transfer I $\mathrm{kg}$ of body mass along a distance I $\mathrm{m}$. If it is assumed that adaptation to running is highest in runners, then this is reflected in the lowest values of $C$ in runners of both sexes against to values in players or non-runners (Bunc and Heller, 1989). The lowest values of $C$ are perhaps the result of running training because these athletes were forced to exercise at very high speed, specifically middle distance runners of both sexes.

The data and results from other groups of endurance oriented athletes suggest that there may be some critical level of maximal functional variables (mainly maximal oxygen uptake) below which an athlete will not be successful. However, above this theoretical critical level, other factors play a more important role in performance.

It should be cautioned that physiological capacities are not the sole predictors of racing success. Nevertheless, they provide significant insights into the basis of endurance performance.

\section{REFERENCES}

Astrand PO, Rodahl K (1986). Textbook of work physiology, 3rd ed. New York: McGraw Hill Book Co.

Balsom PD (1988). The relationship between aerobic capacity, anaerobic power, anaerobic capacity, anaerobic threshold, and performance decrementation in male collegiate soccer players. MSc thesis, Faculty of Springfield College.

Brooks GA (1985). Anaerobic threshold: review of the concept and direction for future research. Med Sci Sports Exerc. 17 (1): 22-31.

Bunc V, Heller J (1989). Energy cost of running in similarly trained men and women. EurJ Appl Physiol; 59:178-83.

Bunc V, Heller J, Leso j; Sprynarova S, Zdanowicz R (1987). Ventilatory threshold in various groups of highly trained athletes. Int J Sports Med; 8: 275-80.

Costill DL (1979). A scientific approach to distance running. Los Altos: Track and Field; 14:12-40.

Cureton KJ, Sparling PB and Evans C. et al. (1978) Effect of experimental alterations in excess weight on aerobic capacity and distance running performance. Med Sci Sports Exerc. 10: 194-9.

Dengel DR, Flynn MG, Costill DL, Kirwan JP (1989). Determinants of succes during triathlon competition. Res Quart Exerc Sport; 60: 234-8. 
Maud PJ, Foster C (1995). Physiological assessment of human fitness. Champaign: Human Kinetics.

O'Toole ML, Douglas PS (1995). Applied physiology of triathlon. Sports Med. 19(4):251-67.

Reilly T, Secher N, Snell P, Williams C (1990). Physiology of sports. E and FN Spon, Champman and Hall: London.

Rhodes EC, Mosher RE, McKenzie DC, Franks IM, Potts JE (1986). Physiological profile of the Canadian Olympic soccer team. Can J App/ Sport Sci. II ( I): 3I-36.

Tumilty D. (1993). Physiological characteristics of elite soccer players. Sports Med 1993, $16(2): 80-96$.

Wilmore $J H$, Costill DL (1994). Physiology of sport and exercise. Champaign: Human Kinetics.

The study was supported by grant from the Czech Ministry of Education No. MSM I 15100001 . 
Série

Investigacão

Coimbra

Imprensa da Universidade

2004 